$$
221^{84^{2}}
$$

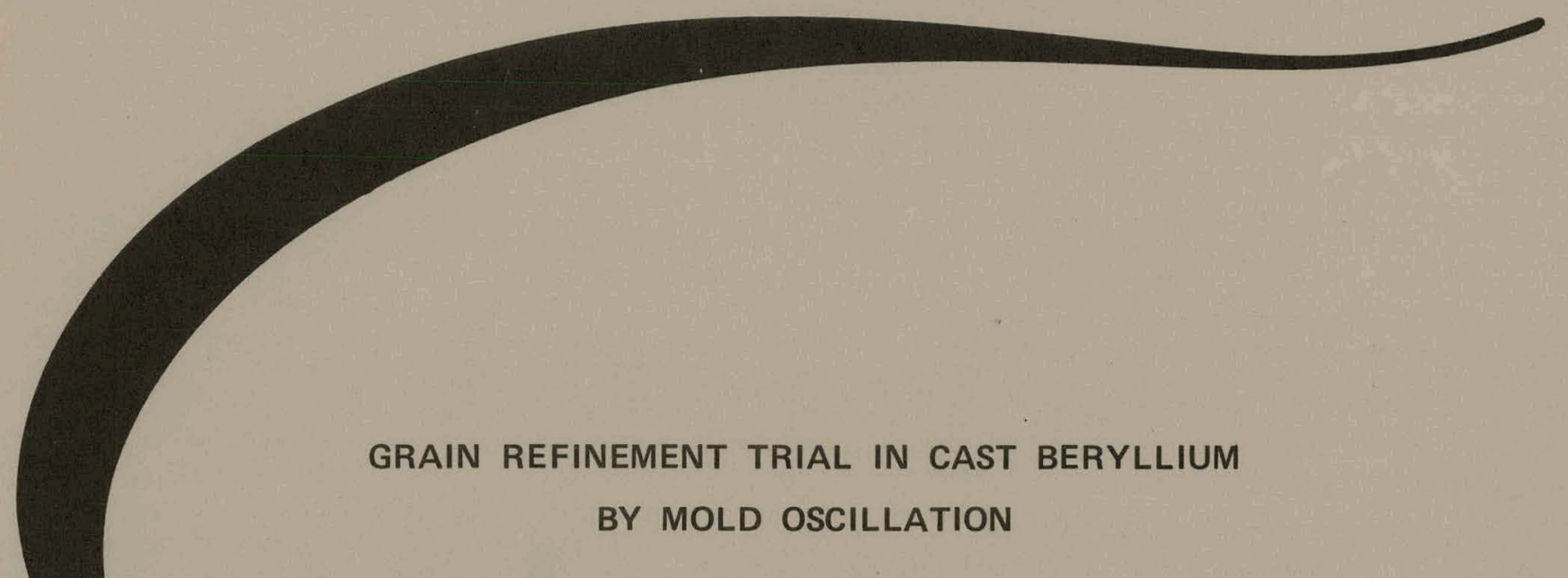

David L. Fergason

Clinton R. Heiple

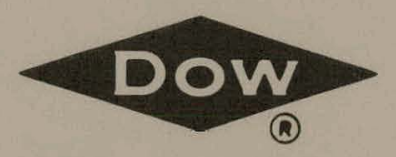

DOW CHEMICAL U.S.A. ROCKY FLATS DIVISION

P. O. BOX 888

GOLDEN, COLORADO 80401

U. S. ATOMIC ENERGY COMMISSION CONTRACT AT(29-1)-1106 


\section{DISCLAIMER}

This report was prepared as an account of work sponsored by an agency of the United States Government. Neither the United States Government nor any agency Thereof, nor any of their employees, makes any warranty, express or implied, or assumes any legal liability or responsibility for the accuracy, completeness, or usefulness of any information, apparatus, product, or process disclosed, or represents that its use would not infringe privately owned rights. Reference herein to any specific commercial product, process, or service by trade name, trademark, manufacturer, or otherwise does not necessarily constitute or imply its endorsement, recommendation, or favoring by the United States Government or any agency thereof. The views and opinions of authors expressed herein do not necessarily state or reflect those of the United States Government or any agency thereof. 


\section{DISCLAIMER}

Portions of this document may be illegible in electronic image products. Images are produced from the best available original document. 


\section{LEGAL NOTICE}

This report was prepared as an account of work sponsored by the United States Government. Neither the United States nor the United States Atomic Energy Commission, nor any of their employees, nor any of their contractors, subcontractors, or their employees, makes any warranty, expressed or implied, or assumes any legal liability or responsibility for the accuracy, completeness or usefulness of any information, apparatus, product or process disclosed, or represents that its use would not infringe privately owned rights.

Printed in the United States of America

Available from the

National Technical Informaliun Service

U. S. Department of Commerce

Springfield, Virginia 22151

Price: Printed Copy $\$ 4.00$ Microfiche $\$ 0.95$ 
Research and Ecology

David L. Fergason

FABRICATION GROUP

Clinton R. Heiple

PHYSICAL METALLURGY GROUP

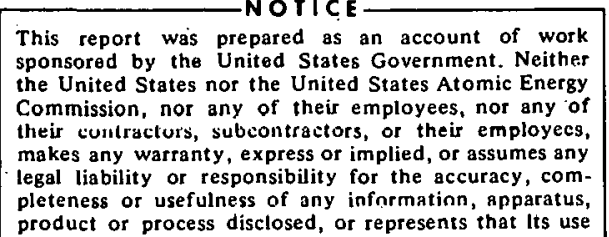

product or process disclosed, or represents that Its use would not infringe privately owned rights.
DOW CHEMICAL U.S.A. ROCKY FLATS DIVISION

P. O. BOX 888

GOLDEN, COLORADO 80401

Prepared under Contract AT(29-1)-1106

for the

Albuquerque Operations Office

U. S. Atomic Energy Commission

\section{SUBBJECT DESCRIPTORS}

Beryllium

Casting

Oscillation

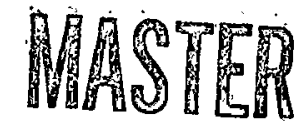


RFP-1840 


\section{CONTENTS}

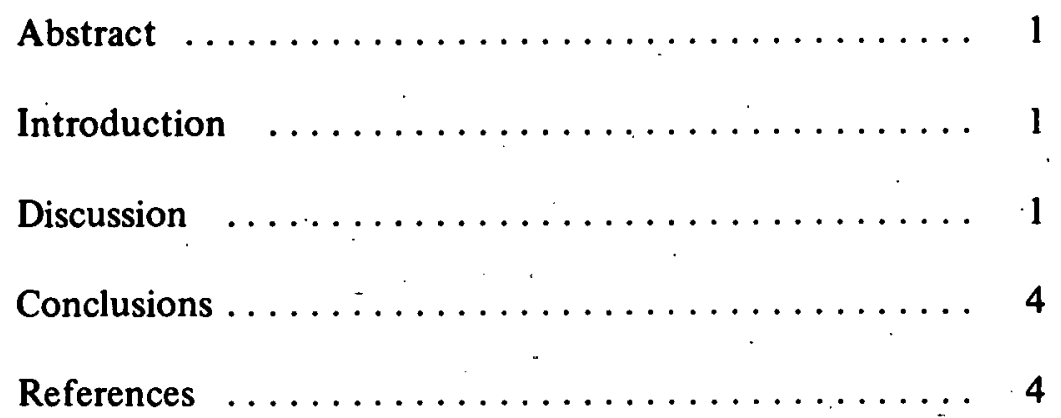


RFP-1840 


\title{
GRAIN REFINEMENT TRIAL IN CAST BERYLLIUM BY MOLD OSCILLATION
}

\author{
David L. Fergason and Clinton R. Heiple
}

\begin{abstract}
Unsuccessful efforts to modify the grain size of cast beryllium by mold oscillation during solidification are described. No change in grain size or growth pattern could be induced within the range of oscillation frequency (up to 72 reversals per minute) and amplitude (up to about 75 degrees between reversals) possible with the apparatus.
\end{abstract}

Achieving a reduced grain size has particular importance in improving mechanical properties of beryllium.

\section{INTRODUCTION}

The mechanical properties of beryllium, produced by warm-working of cast ingots, improve sharply with decreasing grain size $(1,2,3) .^{1}$ Reducing the grain size of castings or converting castings to an equiaxed rather than columnar structure would be desirable because such a change reduces the amount of work necessary to achieve a specific grain size. Recent efforts to modify the grain size of cast beryllium by mold oscillation during solidification have not been successful.

\section{DISCUSSION}

Currently about 90 percent reduction from the ingot is required to generate a small enough grain size in order for sheet to have reasonable mechanical properties. The required reduction imposes a severe limitation on the maximum useful sheet thicknesses which can be produced. Grain-size reduction has been achieved in many alloy systems by mold oscillation during solidification $(4,5,6,7)$. The enforced fluid motion presumably breaks off dendrites at the solid-liquid interface, and the debris form the nuclei of new grains. Oscillations

\footnotetext{
${ }^{1}$ Numerals in parentheses relate to references at end of text.
}

also increase the rate of convective heat transfer and therefore lower temperature gradients in the liquid, which favors survival of the nuclei $(5,6)$. Similar results have been obtained using ultrasonic and lower frequency vibration during solidification (8). Some debate exists as to whether the grain refinement from vibration is caused by the same mechanism as in oscillated castings, cavitation in the melt, or other effects $(7,8)$. However, attempts to refine the grain size of cast beryllium by ultrasonic vibration (9) and low frequency vibration (10) of the melt have failed.

Pure metals do not normally solidify dendritically, at least under conditions attainable in bulk castings (11). Therefore difficulty apparently would be experienced in disturbing the growing beryllium grains by mold oscillation in order to reduce the grain size significantly. Nevertheless, a preliminary trial of this technique on small beryllium castings showed some promise (12), and the potential usefulness of fine-grained castings has such importance that a trial was made. The molds used were larger and the induced fluid motion was greater than in the castings reported earlier (12).

A vacuum-centrifugal casting furnace was modified to produce oscillatory motion of the mold pedestal. The amplitude and frequency of the oscillation were variable. Castings were made in cylindrical molds, 15.2-centimeter $(\mathrm{cm})$ diameter by $22.9 \mathrm{~cm}$ high, and also in $15.2-\mathrm{cm}$ square molds $22.9 \mathrm{~cm}$ high.

No significant difference was evident in grain size or shape for either the square or cylindrical castings between static and oscillated castings up to the maximum oscillation frequency ( 72 reversals per minute) and maximum amplitude (about 75 degrees between reversals) possible with the apparatus. Macrographs of sections containing the axis of the casting for static and oscillated conditions are shown in Figures 1,2, 3, and 4. The differences 


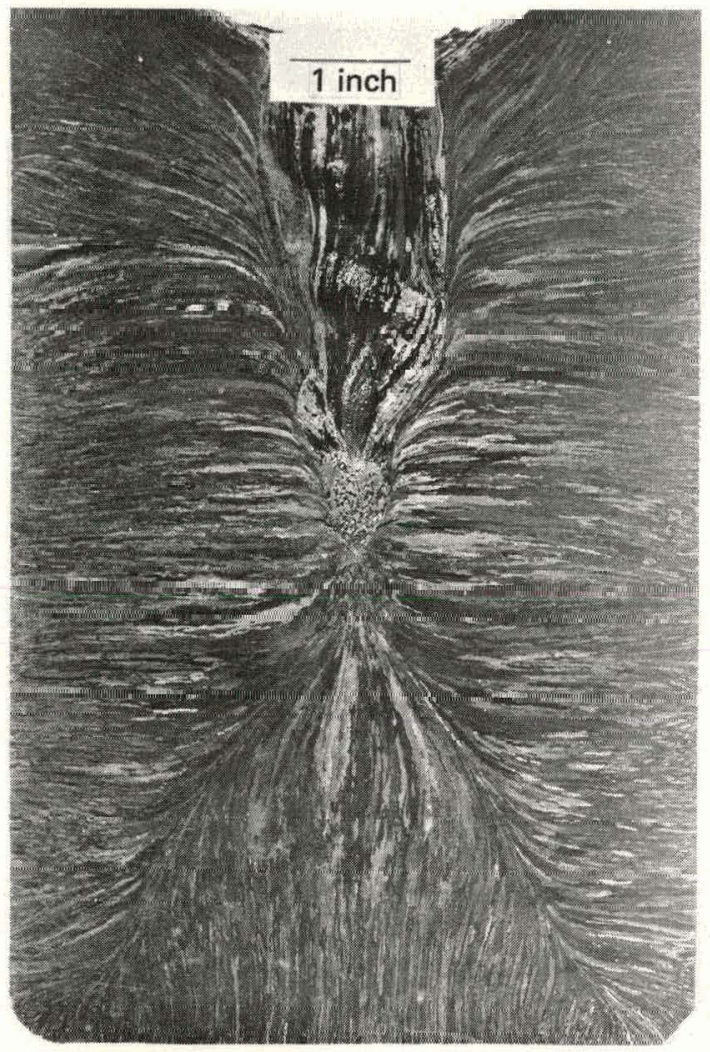

FIGURE 1, Grain Structure Noted

in Static Casting, Square Muld.

FIGURE 2. Grain Structure Noted in Oscillated Casting, Square Mold.

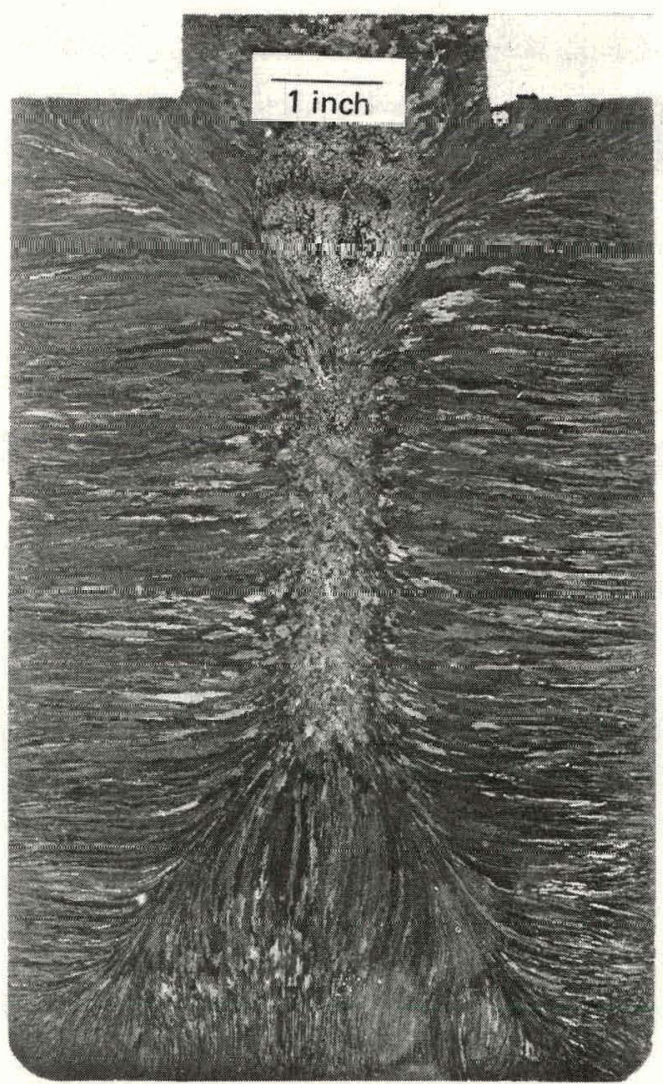


RFP-1840

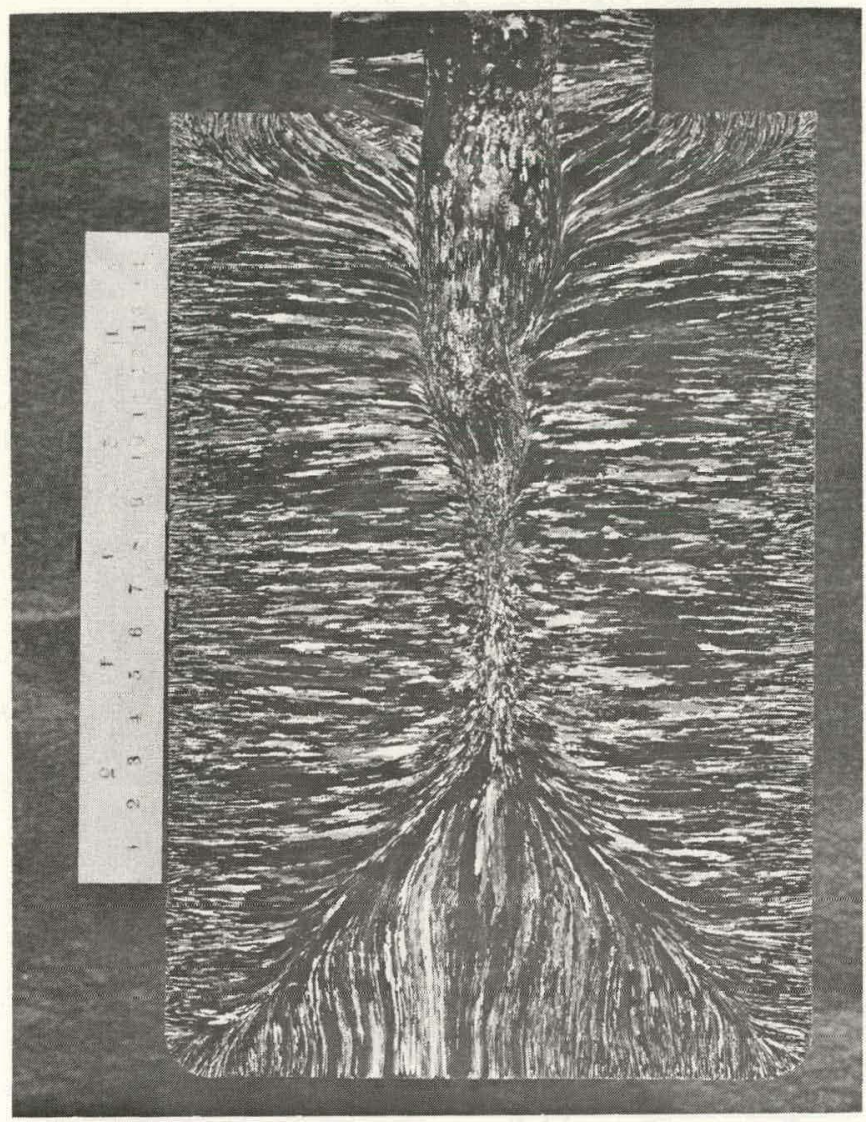

FIGURE 3. Grain Structure Noted in Static Casting, Cylindrical Mold.

FIGURE 4. Grain Structure Noted in Oscillated Casting, Cylindrical Mold.

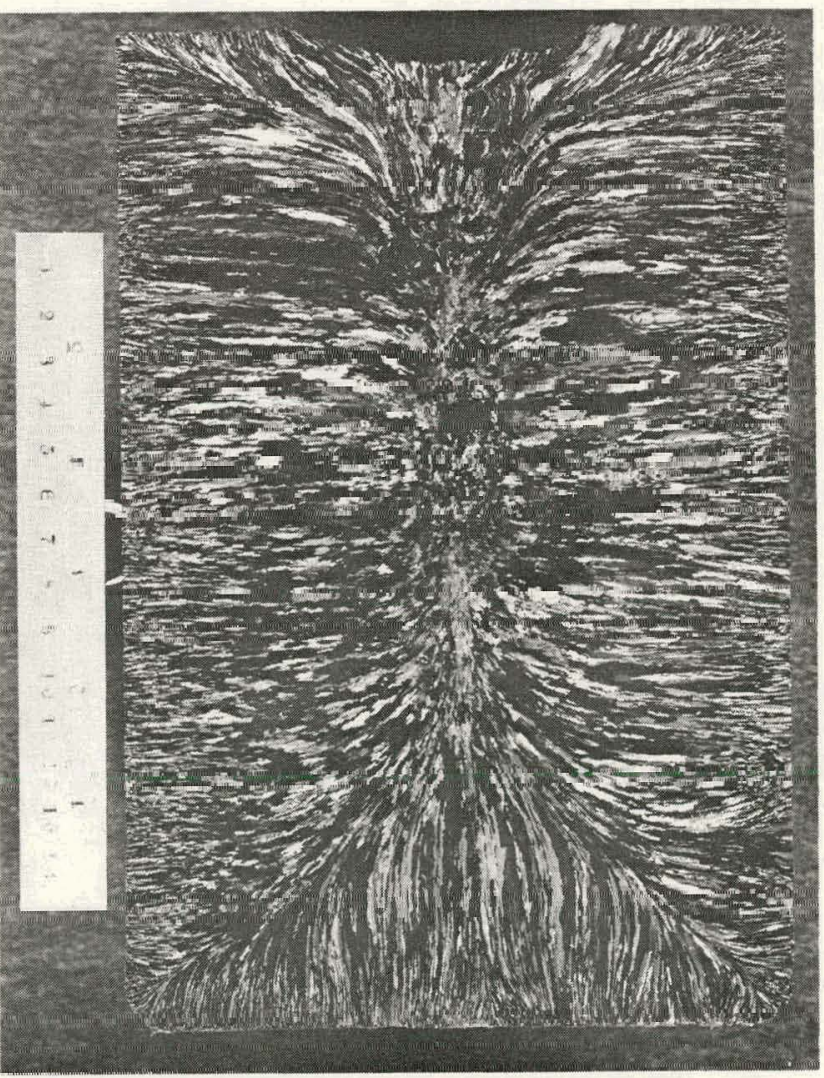


in grain structure between the square and cylindrical castings result from geometry and cooling-rate effects. Techniques exist for producing sound beryllium castings (13), but they were not applied to these castings since the objective was to determine if grain-size reduction could be achieved.

\section{CONCLUSION}

No significant reduction of the cast grain size of beryllium by mold oscillation during solidification has been achieved. More violent fluid motion than attained could possibly reduce the grain size of castings. However no evidence exists in the range of amplitudes and frequencies studied at Rocky Flats to show that increasing fluid motion alters the cast grain size of beryllium.

\section{REFERENCES}

1. J. E. J. Bunce and R. E. Evans. Conference on the Metallurgy of Beryllium. Institute of Metals, London, England. 1961. Page 246.

2. C. I. Bort and A. Moore. Conference on the Metallurgy of Beryllium. Institute of Metals, London, England. 1961. Page 237.

3. W. Taylor. The Influence of Grain Refinement and Titanium Alloying Additions on the Mechanical Properties of Beryllium Ingot Sheet. Kawecki Berylco Industries, Reading, Pennsylvania. Prepared for the Department of the Navy, Air Systems Command, Contract N-0019-69-0233. Washington, D. C. 1970.

4. G. S. Cole and G. F. Bolling. "The Synthetic Equiazed Zone." Transactions of the American Institute for Mining Engineers, 245:725. 1969.

5. G. S. Cole and G. F. Bolling. "Enforced Fluid Motion and the Control of Grain Structures in
Metal Castings." Transactions of the American Institute for Mining Engineers, 239:1824. 1967.

6. M. J. Stewart, L. C. MacAulay, and F. Weinberg. "Macrosegregation in Castings Rotated and Oscillated during Solidification." Metallurgy Transactions, 2:169. 1971.

7. R. T. Southlin. "Grain Refinement of Cast Metals by Vibration." Journal of Australian Institute of Metals, 10:115. 1965.

8. S. L. Hem. "The Effect of Ultrasonic Vibrations on Crystallization Processes." Ultrasonics, 5:202. 1967.

9. N. Marapas and J. B. Jones. Investigation of Ultrasonic Grain Refinement in Beryllium. AEC Report No. NYO-7788. Aeroprojects, Incorporated, West Chester, Pennsylvania. 1957.

10. A. E. Bibb and S. M. Bishop. Grain Refinement of Cast Beryllium. KAPL-1917. Knolls Atomic Power Laboratory, General Electric Company, Schenectady, New Yuk. April 1958.

11. Robert Reed-Hill. Physical Metallurgy Principles. D. Van Nostrand Company, Princeton, New Jersey. 1964. Page 381.

12. K. C. Taber and R. C. Harris. Beryllium C'asting, Phase II. Final Report, September 19, 1958 through December 15, 1960. NP-9958. The Beryllium Corporation, Reading, Pennsylvania. 1961.

13. Julius L. Frankeny and Dennis R. Floyd. IngotSheet Beryllium Fabrication. RFP-910. Rocky Flats Division, The Dow Chemical Company, Golden, Colorado. February 9, 1968. 